\title{
EVALUATIF PENERAPAN MANAJEMEN PENDIDIKAN
}

\author{
Bahrun Ali Murtopo \\ Dosen IAINU Kebumen \\ bahrunalimurtopo@gmail.com
}

\author{
Atikhah Lestari \\ Nuni Nurbaety \\ Mahasiswa IAINU Kebumen
}

\begin{abstract}
Abstrak
Majemen merupakan prosespendidikan merupakan ilmu yang merupakan proses kegiatan pengelolaan sumber daya pendidikan untuk mencapai tujuan pendidikan. penerapanpendidikan dalam lembaga pendidikan merupakan upaya untuk meningkatkan mutu pendidikan. Manajemen Berbasis Sekolah merupakan salah satu produk dari penerapan manajemen dalam lembaga pendidikan.terbukti bahwa dengan adanya otonomi sekolah berupa Manajemen Bersbais Sekolah (MBS) mampu meningkatkan mutu sekolah, apabila mutu sekolah meningkat diharapkan mutu pendidikan juga ikut meningkat. untuk mengukur seberapa efektif kegiatan berjalan, apakah kekurangan dan keburukan dari penerapan kebijakan dan bagaimana mengatasi kekurangan dan hambatan dari pelaksanaan dan penerapan kebijakan.
\end{abstract}

Katakunci: Evaluatif, Peranan, Pendidikan

91

* Volume. 2 No. 1. Tahun 2018

ISSN On-line : 2580-9385

* Manajemen Pendidikan Islam dan Studi Sosial

ISSN Cetak : 2581-0197 


\section{A. PENDAHULUAN}

Manajemen merupakan proses pengelolaan, sedangkan pendidikan merupakan upaya pendewasaan manusia dengan pembelajaran dan pelatihan. Manajemen diimplementasikan kedalam pendidikan menjadi manajemen pendidikan. Manajemen pendidikan merupakan cabang ilmu yang masih relatif muda ${ }^{69}$. Manajemen banyak diterapkan dalam berbagai bidang, salah satunya adalah bidang pendidikan.penerapan manajemen dalam lembaga pendidikan merupakan regulasi kebijakan yang dibuat oleh pemerintah untuk mencapai tujuan pendidikan dengan cara-cara yang efektif dan efisien.

Manajemen pendidikan merupakan terobosan baru yang dilihat lebih efektif untuk memecahkan dan mengatasi persoalan dalam lembaga pendidikan baik dalam sistem pengelolaan dan sistem-sistem lainnya. Pelaksanaan penerapan manajemen dalam lembaga pendidikan menghasilkan banyak produk dengan berbagai manfaat.apa itu manajemen pendidikan? bagaimana penerapan manajemen pendidikan dan apa manfaat manajemen pendidikan bagi lembaga pendidikan? Kami akan menguraikannnya dalam pembahasan, beserta dengan analisis evaluatif tentang penerapan manajemen pendidikan dalam lembaga pendidikan. apakah memang memberikan pengaruh yang dapat mengarahkan pendidikan mencapai tujuan pendidikan yang telah ditetapkan.

\footnotetext{
${ }^{69}$ Sarinah dan Mardalena, Pengantar Manajemen. (Yogyakarta, CV Budi Utama, 2017). Hlm.9
}

\section{2}

* Volume. 2 No. 1. Tahun 2018

ISSN On-line : 2580-9385

* Manajemen Pendidikan Islam dan Studi Sosial

ISSN Cetak : 2581-0197 


\section{B. Hasil dan Pembahasan}

\section{a. Pengertian Manajemen Pendidikan}

Manajemen pendidikan merupakan gabungan dari ilmu manajemen dan pendidikan. Menurut The Liang Gie, manajemen adalah segenap proses penyelenggaraan dala setiap usaha kerjasama sekelompok manusia untuk mencapai tujuan tertentu. ${ }^{70}$

Manajemen itu sendiri mempunyai makna pengelolaan atau pengaturan sedangkan pendidikan merupakan usaha untuk mendewasakan manusiamelalui upaya mengajar dan pelatihan kearah yang lebih baik. Jadi manajemen pendidikan merupakan proses pengelolaan sumberdaya dalam usaha mendewasakan manusia melalui upaya pengajaran dan pelatihan ke arah yang lebih baik.

"Ada empat fungsi manajemen yaitu planning (perencanaan), organizing (pengorganisasian), actuating (pelaksanaan), dan controlling (pengawasan)., ${ }^{, 71}$

Perencanaan merupakan proses mempersiapkan serangkaian keputusan untuk mengambil tindakan dimasa yang akan datang, yang diarahkan kepada tercapainya tujuan-tujuan dengan sarana yang optimal. Apakah perencanaan itu penting? Perencanaan sangat penting, bukan hanya dalam lembaga pendidikan melainkan disegala aspek perencanaan merupakan pedoman penyelesaian dan kerangka kerja.

\footnotetext{
${ }^{70}$ Suharsimi Arikunto dan Lia Yuliana, Manajemen Pendidikan, (Yogyakarta: Aditya Media, 2012), hlm.2-3.

${ }^{71}$ Ibid , hlm. 8.
} 
Tanpa adanya perencanaan yang baik dan matang maka proses pendidikan tidak akan berjalan dengan efektif, dan efisien sehingga tujuan dari pendidikan akan sukit untuk dicapai. Dengan adanya rencana setiap langkah dapat diukur atau dibandingkan dengan hasil yang seharusnya dicapai.

Melalui perencanaan juga meminimalisir terbuangnya uang, tenaga dan waktu secara tidak efektif, dan mampu memepersempit kemungkinan timbulnya gangguan atau hambatan. Pengorganisasian merupakan usaha untuk mewujudkan kerja sama antar manusia yang terlibat kerja sama.

Supaya pencapaian tujuan dari pendidikan dapat tuntas perlu adanya pengorganisasian atau pembagian tugas dalam bidang-bidang tertentu dan ditangani secara khusus oleh orangorang yang menguasai masalahnya.

Pengorganisasian dalam suatu lembaga berfungsi untuk mengetahui batasan-batasan antara bidang yang satu dengan yang lainnya, serta member batasan yang jelas tentang wewenang dan kewajiban masing-masing anggota.

Pelaksanaan merupakan wujud implenentasi dari nperencanaan dan pengorganisasian. Pelaksanaan akan berjalan dengan baik apabila perencanaan dan pengorganisasian juga tertata dengan baik.

Pengawasan merupakan aspek terpenting dalam manajemen, karena pengawasan merupakan analisis tentang pelaksanaan perencanaan.Tujuan utama pengawasan adalah agar dapat diketahui tingkat pencapaian tujuan pendidikan dan menghindarkan terjadinya penyelewengan dalam pelaksanaan perencanaan. Dengan kata lain pengawasan juga dapat diartikan dengan pengendalian. ${ }^{72}$

${ }^{72}$ Suharsimi Arikunto dan Lia Yuliana, Manajemen Pendidikan, (Yogyakarta: Aditya Media, 2012) hlm. 10-13.

94

* Volume. 2 No. 1. Tahun 2018

ISSN On-line : 2580-9385

* Manajemen Pendidikan Islam dan Studi Sosial

ISSN Cetak : 2581-0197 
Empat komponen diatas merupakan dasar dari manajemen pendidikan.

b. Komponen Lembaga Pendidikan

Dalam lembaga pendidikan terdapat komponen-komponen penting yang menentukan keberhasilan lembaga tersebut yaitu:

1. Siswa

Siswa merupakan subjek belajar yang menurut jenis dan sifat lembaganya dapat disebut sebagai peserta khusus.

2. Guru

Merupakan subjek yang memberikan pelajaran pengalaman dan pelatihan kepada siswa.

3. Kurikulum

Yaitu materi atau bahan ajar yang diberikan atau diajarkan dan memeberikan ciri pada lembaga pendidikan tersebut dan mencerminkan kualitas lulusannya.

4. Sarana dan prasarana

Adalah komponen penunjang terlaksananya proses pengajaran

5. Pengelola

Orang-orang yang mengurus pengelolaan lembaga yang bertugas mengelola, mengorganisasikan, mengarahkan dan membina serta mengurus tata laksana lembaga.

Dari setiap komponen lembaga pendidikan harus terjalin kerja sama yang baik supaya tujuan dari

95

* Volume. 2 No. 1. Tahun 2018

ISSN On-line : 2580-9385

* Manajemen Pendidikan Islam dan Studi Sosial ISSN Cetak : 2581-0197 
pendidikan tercapai. perlu adanya sinergi yang berkelanjutan antar komponen.

Disini lah perna manajemen pendidikan dibutuhkan.Karena dengan adanya manajemen pendidikan membantu lembaga pendidikan untuk mendaya gunakan semua sumber-sumber (personil ataupun materil) secara efektif dan efisien guna menunjang tercapainya tujuan pendidikan. ${ }^{73}$

c. Produk Pengimplementasian Manajemen Pendidikan Dalam Lembaga Pendidikan

Lembaga pendidikan merupakan badan atau instansi baik negeri maupun swasta yang melaksanakan kegiatan mendidik. Dalam pelaksanaan kegiatan pendidikanpasti mempunyai tujuan dan cita-cita. Demi mewujudkan citacita dan tujuan tersebut perlu adanya pengelolaan yang tepat supaya proses pelaksanaan pendidikan dapat berjalan secara efektif dan efisien.

Dengan adanya manajemen dalam suatu lembaga pendidikan diharapkan mampu memberikan arah pencapaian kinerja secara terukur dan sistematis sehingga diharapkan dapat berjalan sesuai dengan cita-cita dari pendidikan itu sendiri. Penerapan manajemen dalam lembaga pendidikan salah satunya adalah terbentuknya manajemen berbasis sekolah.

\footnotetext{
${ }^{73} \mathrm{M}$ uhammad, M anajemen Berbasis Sekolah, http://muhammadstainkendari.blogspot.co.id/2014/06/manajemen-berbasis-sekolahseputar.html?m=1, pada 25 Oktober 2017 pukul 14.50
}

\section{6}

* Volume. 2 No. 1. Tahun 2018

ISSN On-line : 2580-9385

* Manajemen Pendidikan Islam dan Studi Sosial

ISSN Cetak : 2581-0197 
Apa manajemen berbasis sekolah itu? manajemen berbasis sekolah merupakan konsep pengelolaan sekolah yang ditujukan untuk meningkatkan mutu pendidikan di era desentralisasi pendidikan. Dimana tenggungjawab dan pengambilan keputusanterhadap pelaksanaan atau penyelenggaraan sekolah telah diserahkan kepada kepala sekolah, guru-guru, para orang tua siswa dan peserta didik/siswa serta anggota komunitas sekolah lainnya.

Pentingnya Manajemen Bersbais Sekolah (MBS) dalam penyelenggaraan dan pengelolaan sekolah yaitu dapat meningkatkan akuntabilitas kepala sekolah dan guru terhadap peserta didik, orang tua siswa dan masyarakat. Manajemen Bersbais Sekolah (MBS) juga memberikan keterbukaan kepada semua pemangku kepentingan dalam memberikan saran dan masukkan untuk penentuan kebijakan-kebijakan penting yang diperlukan oleh sekolah. $^{74}$

Dengan demikian aspirasi dari semua pemangku kepentingan sangat dihargai untuk menjadi bagian penting dalam penentuan kebijakan yang akan diambil oleh lembaga pendidikan sekolah. Komponen dan aspek-aspek manajemen berbasis sekolah

\footnotetext{
${ }^{74}$ Peraturan Pemerintah Republik Indonesia Nomor 19 Tahun 2005 tentang Standar Nasional Pendidikan, Pasal 49, Ayat (1); "Pengelolaan satuan pendidikan pada jenjang pendidikan dasar dan menengah menerapkan manajemen berbasis sekolah yang ditunjukkan dengan kemandirian, kemitraan, partisipasi, keterbukaan, dan akuntabilitas"
}

97

* Volume. 2 No. 1. Tahun 2018

ISSN On-line : 2580-9385

* Manajemen Pendidikan Islam dan Studi Sosial

ISSN Cetak : 2581-0197 
1. Komite sekolah

Salah satu cirri dari Manajemen Bersbais Sekolah (MBS) adalah adanya mitra penyelenggara (komite) sekolah khususnya yayasan dan pimpinan sekolah dalam melaksanakan pelayanan dan proses pembelajaran.

2. Rencana pembangunan jangka menengah dan rencana pembangunan tahunan

Rencana pembangunan jangka menengah memuat visi, misi, strategi dan tujuan jangka menengah pembangunan dan belanja sekolah selama 5 tahun. Rencana ini dikembangkan sebagai hasil analisis data dan hasil audit kinerja awal sekolah.

Rencana pembangunan tahunan merupakan bagian yang terpadu RPJM yang juga mempertimbangkan berbagai kepentingan dan sumber dana dalam jangka tertentu.

3. Adanya sistem keterbukaan dan pertanggung jawaban

Manajemen Bersbais Sekolah (MBS) mempunyai sistem yang terbuka, bertanggung jawab, dan berkelanjutan.Salah satu prinsip Manajemen Bersbais Sekolah (MBS) adalah transparasi dan akuntabilitas sehingga semua komponen dalam lembaga pendidikan dapat mengetahui kebijakan yang disepakati oleh semua pihak yang terlibat dalam sistem manajemen pendidikan tersebut.

4. Kemandirian

98

* Volume. 2 No. 1. Tahun 2018

ISSN On-line : 2580-9385

* Manajemen Pendidikan Islam dan Studi Sosial

ISSN Cetak : 2581-0197 
Maksud dari kemandirian dalam Manajemen Bersbais Sekolah (MBS) adalah setiap pengambilan keputusan dan penyelenggaraan dengan melibatkan partisipasi semua pihak yang berkepentingan dengan sekolah secara demokratis,

5. Pembagian wewenang dan tanggung jawab

Dalam pengelolaan pendidikan perlu adanya pembagian wewenang dan tanggung jawab yang jelas sehingga tidak terjadi tumpang tindih wewenang dan tanggung jawab sehingga akan tercipta kerja sama yang setara, kreatif dan produktif sehingga mampu terhindar dari konflik.

6. Pengembangan kurikulum dan pengajaran Manajemen Bersbais Sekolah (MBS) memberikan otonomi sekolah dalam pengembangan kurikulum seperti muatan lokal yang berbasiskan kebutuhan masyarakat, dunia usaha dan industry.

7. Pendidik dan tenaga kependidikan yang professional Perlunya pendidik yang professional demi terlaksanaanya fungsi pendidikan dengan baik yang memperhatikan etika profesi agar mampu menguasai peserta didik secara bijak dan tepat.

Manajemen Berbasis Sekolah merupakan salah satu bentuk nyata dari penerapan manajemen pendidikan dalam lembaga pendidikan.

Manajemen Berbasis Sekolah melibatkan peran serta masyarakat dari berbagai lapisan sosial atau ekonomi, sehingga masyarakat ikut mendudkung dan merasa bertanggung jawab atas kemajuan mutu pendidikan.Namun 99

* Volume. 2 No. 1. Tahun 2018

ISSN On-line : 2580-9385

* Manajemen Pendidikan Islam dan Studi Sosial ISSN Cetak : 2581-0197 
sampai sekarang dukungan tersebut lebih banyak pada bidang fisik dan materi seperti membantu pembangunan gedung, merehab sekolah, memperbaiki fasilitas sekolah dan sebagainnya ${ }^{75}$.

Masyarakat juga dapat membantu dalam bidang teknis edukatif, seperti menjadi pendidik bantu, pendidik pengganti, mengajarkan kesenian, ketrampilan, atau agama. Tetapi amat disayangkan bahwa hal tersebut belum banyak dilakukan.Sebenarnya mereka mempunyai potensi untuk membantu sekolah yang memberikan pembelajaran pada anak-anak mereka. Tetapi ini bergantung pada bagaimana cara sekolah mendekati masyarakat tersebut.

Sekolah harus mengetahui cara mendorong peran serta masyarakat agar mereka mau membantu sekolah, sebaliknya dalam prakteknya Komite Sekolah yang seharusnya menjadi pendukung sekolah untuk memobilisasi sumber daya malah menjadi beban baru bagi sekolah dan orang tua peserta didik dalam pembiayaan dan manajemen.

d. Prinsip Manajemen Pendidikan Dalam Lembaga Pendidikan Manajemen pendidkan mempunyai beberapaprinsip yaitu: ${ }^{76}$

1. Beriorientasi pada tujuan dengan menetapkan tujuantujuan yang harus dicapai peserta didik dalam mempelajari pelajaran.

75 "Undang-Undang Republik Indonesia Nomor 22 Tahun 1999 tentang Pemerintah Daerah" yang kemudian diikuti pedoman pelaksanaannya berupa "Peraturan Pemerintah Republik Indonesia Nomor 25 Tahun 2000 tentang Kewenangan Pemerintah dan Kewenangan Propinsi sebagai Daerah Otonomi.

${ }^{76}$ Suryosubroto, Manajemen Pendidikan Di Sekolah. (Pt Rineka Cipta, Jakarta, Pt Asdi Mahasatya, 2014) Hlm-10-15

100

* Volume. 2 No. 1. Tahun 2018

ISSN On-line : 2580-9385

* Manajemen Pendidikan Islam dan Studi Sosial

ISSN Cetak : 2581-0197 
2. Efisiensi dan efektifitas dalam penggunaan dana,daya dan waktu dalammencapai tujuan pendidikan.

3. Pada fleksibilats program, dalampelaksanaan suatu program hendaknya mempertimbangkan faktor-faktor ekosistem dan kemampuan penyediaan fasilitas yang menunjang.

4. Prinsip kontinuitas dengan menyiapkan peserta didik agar mampu melanjutkan ke jenjang yang lebih tinggi

5. Prinsip pendidikan seumur hidup, yang memandang bahwa pendidikan tidak hanya di sekolah tetapi harus dilanjutkan dalam keluarga dan masyarakat.

6. Prinsip relevansi suatu pendidikan akan bermakna apabila kurikulum yang dipergunakan relevan (terkait) dengan kebutuhan dan tuntutan masyarakat.

e. Analisis Evaluative Terhadap Penerapan Manajemen Pendidikan

Evaluasi dalam sebuah lembaga pendidikan merupakan hal yang harus dilakukan supaya program ataupun kebijakan yang telah dilaksanakan dapat diketahui apakah berjalan efektif sesuai dengan yang diharapkan. Dalam mengkaji masalah yang dihadapi, rumuskan solusi alternative yang dapat memperbaiki kelemahan-kelemahan yang ada dan meningkatkan kualitas keberhasilan di masa yang akan datang.

Evaluasi sebagai fungsi manajemen merupakan aktifitas untuk meneliti dan mengetahui serta menganalisis pelaksanaan yang telah dilakukan dalam proses keseluruhan oraganisasi dalam hal ini lembaga pendidikan, untuk mencapai hasil sesuai dengan rencana atau program yang telah ditetapkan guna mencapai tujuan pendidikan. dengan mengetahui kesalahan-

101

* Volume. 2 No. 1. Tahun 2018

ISSN On-line : 2580-9385

* Manajemen Pendidikan Islam dan Studi Sosial ISSN Cetak : 2581-0197 
kesalahan dan kekurangan-kekurangan, perbaikan dan perencanaan solusi yang tepat dapat ditemukan dengan mudah.Analisis evaluasi dilakukan pada semua komponen lembaga pendidikan.

1. Evaluasi penerapan manajemen peserta didik/siswa Bagaimana implementasi manajemen terhadap proses pembelajaran pada siswa, apakah dengan adanya manajemen pendidikan mampu mengarahkan siswa mencapai tujuan pendidikan, ataupun sebaliknya. Faktanya manajemen pendidikan mampu ngarahkan peserta didik untuk mencapai tujuan pendidikan, karena dengan adanya manajemen dapat meningkatkan mutu peserta didik.

2. Evaluasi penerapan manajemen pendidik/guru Manajemen tidak hanya diterapkan pada peserta didik, tetapi guru juga termasuk dalam penerapan manajemen. Adanya pembagian tugas antara guru satu dengan guru lain dapat mempermudah fokus guru dalam melakukan proses pencapaian tujuan pendidikan. evaluasi terhadap penerapan manajemen guru dapat dilakukan dengan mennganalisis bagaimana kinerja guru dalam proses pembelajaran dan bagaimana guru mampu mengatasi masalah yang ada dalam proses pembelajaran, dalam pengupayaan tercapainya tujuan pembelajaran.

3. Evaluasi penerapan manajemen kurikulum

Kurikulum merupakan hal yang sangat penting dalam proses pendidikan. tanpa adanya kurikulum pendidikan tidak akan berjalan dengan baik, karena kurikulum merupakan dasar atau patokan dalam pembelajaran.

102

* Volume. 2 No. 1. Tahun 2018

ISSN On-line : 2580-9385

* Manajemen Pendidikan Islam dan Studi Sosial ISSN Cetak : 2581-0197 
Pengelolaan kurikulum yang tepat akan berpengaruh dengan sukses tidaknya pembelajaran. evaluasi terhadap kurikulum sangat penting dilakukan. Apakah kurikulum masih efektif digunakan untuk pembelajaran ataukan harus ada perubahan regulasi kebijkan tentang kurikulum supaya lebih efektif diterapkan.

4. Evaluasi sarana dan prasarana

Sarana prasarana memang bukam merupakan komponen utama dalam proses pendidikan, melainkan komponen pendukung. Akan tetapi tanpa adanya perencanaan dan pemanfaatan yang baik dari sarana prasarana maka kegiatan pendidikan tidak akan maksimal. Perlu adanya evaluasi tentang sarana prasarana, sudah maksimal dan efektifkan pemanfaatan dari sarana dan prasarana yang ada di lembaga pendidikan.Bagaimana peran dari sarana prasarana tersebut mampu meningkatkan mutu pendidikan.

Evaluasi dilakukan untuk mengetahui seberapa hal yang sangat penting bagi para pendidik dan anak-anak didiksekaligus bagi llembaga pendidikan, yaitu:

1. Perkembangan prestasi anak didik;

2. Baik-buruk, tepat tidaknya metode pembelajaran yang diterapkan oleh para pendidik;

3. Kemampuan, minat dan bakat anak didik dalam bidang studi atau jurusan yang dipilihnya;

4. Profesionalitas para pendidik;

5. Ketepatan kurikulum yang dijadikan rujukan pembelajaran;

6. Strategi pembelajaran yang baik dan tepat untuk diterapkan;

7. Evaluatif pelaksanaan kegiatan pembelajaran;

103

* Volume. 2 No. 1. Tahun 2018

ISSN On-line : 2580-9385

* Manajemen Pendidikan Islam dan Studi Sosial ISSN Cetak : 2581-0197 
8. Kondisi objektif para pendidik dan anak didik berkaitan degan tugas dan fungsunya masing-masing atau mengenai hak dan kewajibannya. ${ }^{77}$

\section{Kesimpulan}

Majemen pendidikan merupakan ilmu yang merupakan proses kegiatan pengelolaan sumber daya pendidikan untuk mencapai tujuan pendidikan. penerapan manajemen pendidikan dalam lembaga pendidikan merupakan upaya untuk meningkatkan mutu pendidikan. Manajemen Berbasis Sekolah merupakan salah satu produk dari penerapan manajemen dalam lembaga pendidikan.terbukti bahwa dengan adanya otonomi sekolah berupa Manajemen Bersbais Sekolah (MBS) mampu meningkatkan mutu sekolah, apabila mutu sekolah meningkat diharapkan mutu pendidikan juga ikut meningkat.

Dalam proses tersebut perlu adanya pengawasan dan evaluasi untuk mengukur seberapa efektif kegiatan berjalan, apakah kekurangan dan keburukan dari penerapan kebijakan dan bagaimana mengatasi kekurangan dan hambatan dari pelaksanaan dan penerapan kebijakan.

${ }^{77}$ Hikmat, M anajemen pendidikan, (Bandung: Pustaka Setia, 2009), hlm.125-126.

104

* Volume. 2 No. 1. Tahun 2018

ISSN On-line : 2580-9385

* Manajemen Pendidikan Islam dan Studi Sosial

ISSN Cetak : 2581-0197 


\section{Daftar Pustaka}

Arikunto, Suharsimi DKK. 2012. Manajemen Pendidikaan. Yogyakarta: Aditya Media.

Sarinah dan Mardalena, 2017, Pengantar Manajemen. (Yogyakarta, CV Budi Utama)

Peraturan Pemerintah Republik Indonesia Nomor 19 Tahun 2005

Suryosubroto, 2014, Manajemen Pendidikan Di Sekolah. (Pt Rineka Cipta, Jakarta, Pt Asdi Mahasatya.

Muhammad. 2014. Manajemen Berbasis Sekolah, ( Yogyakatara. Cv Media)

Hikmat. 2009. Manajemen Pendidikan.Bandung: Pustaka Setia.

"Undang-Undang Republik Indonesia Nomor 22 Tahun 1999 tentang Pemerintah Daerah

http://muhammadstainkendari.blogspot.co.id/2014/06/manajemen-berbasissekolah-seputar.html?m=1(25 Oktober 2017)

* Volume. 2 No. 1. Tahun 2018

ISSN On-line : 2580-9385

* Manajemen Pendidikan Islam dan Studi Sosial

ISSN Cetak : 2581-0197 